\title{
IDENTIFICATION OF ECONOMIC AND LEGAL PRECONDITIONS FOR RENT ACCOUNTING
}

\author{
Sergii Bardash' \\ Kyiv Cooperative Institute of Business and Law, Ukraine \\ Tetiana Osadcha² \\ Kherson State University, Ukraine
}

\begin{abstract}
The urgency of the research consists in the existence of challenging issue regarding the equitable distribution of existing natural resources between existing and future generations, the question of formation, distribution, and use of rent. The economic theory clearly identifies features of rental relations at the government level, but there is no information on accounting reflection of rent as one of the types of income of an economic entity in bookkeeping. Level of information content about rental income remains problematic. This leads to a targeted reduction in the availability of information on income from the use of rental resources since none of the forms of existing types of reporting provides any information on any type of rent. The purpose of the research was to specify the accounting component of rent as an economic category, as well as to determine legal and economic preconditions for rent accounting. The methodological basis of the research is the dialectical method of knowing the essence of the rent and rental relations; general scientific methods of scientific knowledge (analysis, abstracting, synthesis, generalization), bibliographic method of transformation of economic essence and legal content of rent and rental relations, analysis of legal acts in the part of implementation of the contract of rent, method of grouping of economic and legal preconditions for establishing an effective segment of rent accounting. Scientific results. It was established that transformation of the modern mechanism of fragmentary regulation of rental should occur systematically, with obligatory improvement of accounting methods of rent resources and development of a method for calculating rental income, as well as a taxation system of extra profits taking into account specific sources and conditions for the formation of various types of rent. With the purpose of transformation of rental relations in the part of the improvement of accounting of income including rents, legal and economic preconditions for rent accounting are identified. In particular, it was established that the legal basis for accounting of the results of rental relations is the identification of the entity, to which the object belongs (rent-forming factor (resource)); of the entity that uses the object (rent-forming factor (resource)); of the mechanism of implementation of rental relations; of an indisputable reason for calculating the rental factor (resource), - a contract of rent or other legal instrument regulating rental relations. The main economic preconditions necessary and sufficient for the organization and keeping of rent accounting by the economic entity are as follows: an object, - the rent-forming factor (resource), which the economic entity-rent payer uses (exploits); economic benefit from the use (operation) of such an object; income of the entity that uses (exploits) such an object that includes the rent; rent estimation for determining rental income, a share of rent in income from a certain type of activity and subsequent implementation of rent payment; documenting and accounting of rent accounts (rental income) and rent payment, followed by their reflection in the financial statements of the business entity-rent payer. The practical significance of the research is to identify preconditions for the formation of a rent accounting methodology, as well as to form information support for analysing the competitiveness of business entities and determining their financial stability.
\end{abstract}

Key words: rental relations, rent, rent resource, contract of rent, rent accounting.

JEL Classification: M41, P4, Q2

\footnotetext{
Corresponding author:

${ }^{1}$ Department of Finance, Kyiv Cooperative Institute of Business and Law.

E-mail: serg.bardash@gmail.com

${ }^{2}$ Department of Economics, Finance and Entrepreneurship, Kherson State University.

E-mail: tatiana@osadcha.com
} 


\section{Introduction}

The concept of sustainable development is aimed at harmonization of economic, social, environmental components of social development and allows overcoming the consequences of the economic crisis, increasing social development of society, solving the problems of preservation of the environment. One of the problematic issues of the fair distribution of existing natural resources between existing and future generations is the issue of formation, distribution, and use of rent.

Rental relations are one of the important components of the market economy and, in general terms, are relations that arise between social and economic agents regarding the distribution of rental resources. The theory of rent has undergone a long-term evolution in the development of economic science, in the process of which approaches to the definition of the rent itself have changed.

In the most general sense, rent is defined as a special type of stable fixed unearned income, not directly related to any form of entrepreneurial activity, obtained by the owner of limited resources or rights as a result of their exploitation. It is an economic form of enforcement of the property right in its pure form (Hurovska, 2011).

The economic history of human development testifies that rental relations arose along with private ownership of land. In the process of social development, rental relations have undergone significant transformations, as well as new types of rent have arisen. The above changes testify that issues of rent and rental relations have not lost their urgency, because with the development of modern civilization, the results of redistribution of property objects, including objects that can be rentable.

The economic theory clearly identifies features of rental relations at the government level, but there is no information on accounting reflection of rent as one of the types of income of the economic entity in bookkeeping, with the exception of individual publications, in particular, monographs (Osadcha, 2016).

Level of information content about rental income is enough problematic. This leads to a targeted reduction in the availability of information on income from the use of rental resources since none of the forms of existing types of reporting provides any information on any type of rent.

Lack of attention to rent significantly increases the risk of an inadequate estimation of the financial condition of business entities and affects the objectivity and effectiveness of management decisions. As a result, it is necessary to develop theoretical and methodological provisions and develop organizational and practical provisions of rent accounting, which will enable the formation of comprehensive and reliable information for managing income of the enterprise.

\section{Review of recent issues}

Some aspects of the transformation of rental relations in post-socialist economies are analysed in the issues of S. Arkhiyereyev, V. Basilevych, A. Hrytsenko, V.Dementiev, B. Kvasniuk, B. Kuzyk, D. Lvov, O. Nosova, A. Oleynyk, O. Paskhaver, V. Polterovych, P. Sabluk, V. Tambovtseva, Y. Yakovets, and other scientists.

However, despite the undeniable achievements of domestic and foreign economic thought in the development of the theory of rent, the problems of the formation and development of rental relations in the economies of the post-Soviet countries, imperfect functioning and governmental regulation of rental relations remain not developed enough.

Another important problem that should be finally solved is the essential identification of rent in the system of accounting concepts since it is impossible to estimate its value and determine the impact of rent on the formation of income of social and economic agents without this aspect. In recent years, issues of accounting as an information source for managing a particular type of rent were raised. Thus, the issue of particular types of rent was studied by such authors as S. Vehera, V. Zhuk, I. Zamula, S. Zdan [Melnyk], T. Ostapchuk, D. Pankov. Highly appreciating the researches of these and other scientists in the field of accounting, it should be recognized that rent as an economic category, with the exception of rent payments, remains outside the conceptual framework of accounting.

The research purposes and objectives are to clarify the accounting component of rent as an economic category, as well as the definition of legal and economic preconditions for accounting rent.

\section{The statement of basic results}

Permanent transformation of economic relations causes a change in views as to the understanding of rent as an economic category. After analysing a number of scientific works (Bodnar; Hurovska, 2011; Dvihun, 2008; Meshcherov, 2006; Paskhaver, 1972) devoted to the genesis of the theory of rent, it was established that the views of scientists on the essence of rent in a certain way have evolved. Thus, the representatives of classical political economy, in particular, W. Petty, A. Smith, D. Ricardo, J. Mill suggested that rent was a product of nature adjusted to the expenditures of resources and labour; accordingly, the natural resource rent had a double understanding of the natural resource rent as a product of nature and product of labour. D. Ricardo's doctrine of rent acquired a theoretical and practical character based on the definition of the value given by A. Smith and the views on private ownership of land. According to a number of researchers (A.G. Zeldner (Zeldner, 2003), R.P. Kudiyashova (Kudriashova, 2003), V.A. Meshcherov (Meshcherov, 2006)), from the D. Ricardo's time up to the present, virtually no significant 
development in the aspect of the synthesis of the theory of value and rent (Bodnar) has occurred, because he defined rent as an economic category and insisted on the mistakes of the mixing of rent with the lease payment, by which he derived rent from the categories of everyday life in the category of economic theory.

K. Marx and later V. Lenin considered rent as added value, which is caused by an excess of the cost over the price of production. Rent was considered as a transformed form of value-added, similar to profit, wages, and interest. K. Marx saw the emergence of rent as an economic category not in the sphere of production, but in the sphere of distribution, where profit is transformed into rent (Bodnar).

Thus, in the context of the labour theory of value and under the conditions of the market capitalist economy, rent was considered as one of the forms of value added, and as its excess above the average profit in the industry.

Representatives of the neoclassical school (A. Marshall, E. Böhm-Bawerk, L. Walras) considered rent as the excess profit of the resource over the alternative cost of its use. Accordingly, representatives of institutionalism, in particular, J. Buchanan, G. T. Tolleson, A. Krueger consider rent as a result of competition-restricting in order to obtain monopoly rights (Moshenets, 2009).

In the vast majority of countries of the post-Soviet area, which adhered to the doctrines of the command and administrative economy in their social and economic life and did not recognize the private ownership of the means of production, the idea of rent understanding was somewhat different from the views of scientists from other countries since rent was seen as "income from capital, land or property that their owners receive on a regular basis without engaging in entrepreneurial activity. ...The growth of the number of capitalists who receive rent in the era of imperialism is one of the manifestations of parasitism and decay of capitalism at its monopolistic stage" (Economic Dictionary, 1973).

During the time of independent Ukraine, the concept of rent has not changed significantly, since the latter has been considered as:

- a special type of stable unearned income received from capital, land, property, securities etc., not related to entrepreneurial activity (Economic Encyclopaedic Dictionar, 2006);

- any income, regularly received from real estate, land, bonds, which does not require entrepreneurial activity from its recipients (Modern Legal Encyclopaedia, 2009);

- a fee that is established for the use of land and other resources that are the property of other economic entities, provided that their offer is limited (Bazylevych, 2008);

- periodic payment in the form of cash payments or their natural equivalent, carried out in place of the received property (Anomalies in the civil law of Ukraine, 2007);
- surplus income, which should be considered as a part of the economic effect of using the economic resources of society (Hurovska, 2011);

- additional profits that the user of natural resources encounters due to the legal use of resources owing to their rarity, restriction and different approaches to the efficiency of use (Zakharchuk, 2011).

To outline the existing pluralism of thoughts as to the essence of rent, some results of the study set forth in the publication (Moshenets, 2009) deserve attention, according to which rent is considered as:

- the price for the use of land and other natural resources, the quantity of which is limited;

- any payments to the owner of rights to resources that exceed the income, which can be obtained in the non-monopoly use of these resources, that is, under conditions of market competition;

the level of payment for a factor of production that exceeds the minimum payment required to obtain the necessary offer of this factor within the specified method of its use;

- the fee for any resource, the offer of which is maintained at a constant level without costs, but cannot be increased and, accordingly, does not depend on the price;

- the form of expression of excess profits received as a result of the exploitation of limited resources not uniform in quality.

At the level of modern researches of rental relations, according to T. Hurovska (Hurovska, 2011), it is possible to distinguish various types of rent, combining them into two groups according to resource sources: 1) natural rent resource is excess (additional) profit, which arises when using limited natural resources not uniform in quality (Kuzyk, 2004); 2) unnatural (economic) rent is an additional profit obtained without the entrepreneurial efforts and labour costs arising from the use of resources that do not belong to natural wealth (natural resources) - financial, intellectual, and administrative (power) resources. However, it is difficult to agree with the view as to the economic rent, which, according to the author of the paper (Hurovska, 2011), is income earned without entrepreneurial efforts because the use of, for example, intellectual resources causes certain entrepreneurial efforts and forms certain labour costs.

Therefore, analysing the above definitions, it should be noted that rent is considered simultaneously as the payment for use of limited resources (some factors of production); surplus income, additional income from the use of a certain resource in the field of management; passive income, which does not require entrepreneurial activity from its recipients.

The presented polymorphism of the essence of rent the lack of a single approach to the definition of rental income - stipulates the fact that rental nature of income was almost not considered until now in the accounting, 
because, as S. Zdan (Melnyk) correctly states, this is a rather complex aspect of the income part of the enterprise, so it is very difficult to determine the size of rent, and as a result, to reflect it in the accounting (Zdan (Melnyk), 2011).

It is worth paying attention to the fact that rent is also considered as a legal concept, namely:

- risk (aleatory) transaction, according to which the ownership of the property is transfer as a security of future needs of the recipient (Anomalies in the civil law of Ukraine, 2007);

- the generalized concept of the contract of rent, the type of independent civil-law obligation, with its general and specific features (Anomalies in the civil law of Ukraine, 2007);

- a form of payment as a certain amount of money or other provision provided by the contract of rent (Anomalies in the civil law of Ukraine, 2007).

The latter definition according to the thought set forth in the publication (Anomalies in the civil law of Ukraine, 2007) should be regarded as a narrow understanding of rent, which itself was reflected in separate legal regulatory instruments. The confirmation of this position is an overview of the legal regulatory documents, according to which rent is an established (fixed) amount paid to the individual periodically during the specified period of the lifetime or for a specified or established period of time in accordance with the obligations to make payments in exchange for an adequate and full remuneration (Convention between the Government of Ukraine and the Government of the Italian Republic...; of the Republic of India...; of the Federal Republic of Brazil; Agreement between Ukraine and the Republic of Tajikistan...).

Without excluding a narrow understanding of rent as a legal concept from the scope of considerations, we consider as non-alternative the statement that: "Any rent is a form of enforcement of the right of ownership for the respective resource. All types of ... rent are a kind of income received by economic agents by including a monopoly or exclusive right to use a limited resource and, at the same time, limiting access to it by other agents, which is caused by peculiarities of origin, involvement, and use of the resource itself" (Hurovska, 2011).

Thus, implementation of rental relations is carried out through a special economic mechanism for creation and distribution of value added, which is a set of market, legislative, organizational, administrative, and other measures that affect the behaviour of participants in the field of economic relations and form a material interest in participation in the production process. In such an interpretation, A.O. Dvihun (Dvihun, 2008) states, the economic mechanism of realization of rental relations can be defined as a separate rent mechanism, which should be understood as a set of production and organizational structures, a system of legal regulations, a set of forms and methods of management, through which the process of creating, distributing, assigning, and withdrawing income from the use of resources is used in accordance with property rights and other resources involved in the production process.

Consequently, in the broad context, modern rental relations appear as a combination of economic, legal, and psychological (economic and non-economic) relations between participants in agreements on the formation and use of rental resources and income. At the moment, one should agree with the statement that one of the specific features of modern rental relations is "... dependence on institutional principles of enforcement of property rights on the rent-producing resources. Modern rental relations appear as a complex system of interactions of agents of a market economy associated with the appropriation of special forms of income from enforcement of exclusive property rights to rental resources (Hrazhevska, 2015). Taking into account that an important precondition for the effective functioning of rental relations is the control of access to these resources on the basis of clearly defined and protected property rights, the only effective tool for achieving the goal is an accounting of the consequences of rental relations.

Consideration of the possibility of rent accounting as one of the consequences of rental relations will remain incomplete without considering their legal aspects, in particular, the form of documentary registration of rental relations, the definition of the subject and the subjective composition of rental relations. A significant contribution to the formation of legal regulation of rental relations was made owing to the researches of such scientists as M. Apanasiuk, V. Baliuk, M. Braginsky, V. Vitryansky, N. Zolotko, R. Maidanyk, I. Timush, E. Yarygin, and others.

The importance of legal aspects of rent accounting is that the identification of counteragents becomes relevant, one of which will pay a rent payment from the income/profit, and the other will receive a rent-income (passive or active depending on the circumstances and type of resource). It is also worth remembering that payments will be made only on the basis of legal instruments, in particular, the contract of rent - a civil law contract, according to which one party (the rent recipient) transfers property to the other party (the rent payer), and the rent payer is obliged, in exchange for the property received, to pay periodically to the recipient rent in the form of a certain amount of money or provision of funds for its maintenance in a different form (Part 1 of Article 371 of the Civil Code of Ukraine) (Kharytonov, Kalitenko, 2004).

In the context of this research, the issue of the subject of rental relations becomes particularly relevant: in particular, what exactly can cause a rent. It should be noted that among the experts in jurisprudence, there is no unity on this issue, as the subject of the contract of rent (rental relations) can be: 
- any individually determined property not removed from civilian circulation, which has both generic and individual identifiable characteristics, the use of which in the business activity or in order to meet the own needs of the payer of rent contributes to the formation of property income ... except for inalienable intangible benefits, such as personal non-property rights, ideas, intangible results of intellectual activity, services (Civil law of Ukraine: a series of lectures, 2006);

- property rights, information, results of intellectual activity, including rights to them, the performance of works and provision of services for the same purpose (Sukhanov, 2005);

- property (not only things and their aggregate, but also property rights and obligations, including information, results of intellectual activity and exclusive rights to them, performance of works and provision of services), which is transferred for the payment of rent, as well as rent itself (as in the form of money and by providing things, performing works or providing services) (Civil law of Ukraine: study guide, 2005);

- just the things, because ... the contract of rent differs from other agreements, which are also aimed at the alienation of property to ownership by the fact that its subject cannot be property rights, as well as the right to claim (Baliuk);

- things (including money and securities), an aggregate of individual objects (universitas rerum distantium), as well as property rights, since in the relevant articles on the contract of rent of the Civil Code of Ukraine, there are no restrictions as to what is meant under the property for this type of contract, and also on the basis of the definition of the property stipulated by Article 190 of the Civil Code of Ukraine (Pospolitak, 2010).

To determine preconditions of rent accounting, and hence rental relations, the identification of their subjects is important. According to Articles 731, 733 of the Civil Code of Ukraine, which should be applied in conjunction with other articles of Chapter 56 of the Civil Code of Ukraine, such entities are:

- the rent recipient on the one hand - the property owner, who transfers this property to another person in exchange for receiving periodic rent payments in cash or in kind;

- the rent payer on the other hand - the person acquiring the property rights transferred by the rent recipient in exchange for the obligation to pay rent to the recipient in the form of a certain amount of money or other provision.

From the perspective of the right, essential for the realization of rental relations under the terms of the contract of rent is that the rent recipient must be the owner of the property, which is transferred under the rent payment, since this contract is aimed at the transfer of ownership of the property. In case of transfer of property rights under the rent payment, the alienator must be endowed with these rights (that is, they have the right to exercise them) (Pospolitak, 2010).

Important is the fact that the codified law does not limit the subject structure of the participants in the contract of rent. At present, according to Article 733 of the Civil Code of Ukraine, parties to the contract of rent may be natural or legal entities. The Civil Code of Ukraine also determines that the payer and the recipient of rents may be both natural and legal entities possessing civil legal capacity and capability, which can in full without any restrictions, act as payers or recipients of rent.

Some scientists are of the opinion that "The social nature of the contract of rent implies that the recipient of rent must be an entity who does not engage in entrepreneurial activity" (Civil Code of Ukraine, 2004). However, an analysis of the regulations of Chapter 56 of the Civil Code of Ukraine, as well as general provisions on obligations and contracts, taking into consideration the basis of formal logic carried out by V. Pospolitak and R. Khanyk-Pospolitak, gave to the researchers sufficient grounds to conclude that there was no restriction on the subject composition of the rent recipients under the Civil Code of Ukraine (Pospolitak, 2010). At the moment, it should also be taken into account that both commercial and non-commercial legal entities can be the rent recipients. The fact that rent is considered as an income, which is not related to entrepreneurial activity, does not prevent it from being received by business entities, such as commercial banks (Apanasiuk, 2004). Natural entities-business entities are actually equated with legal entities in their status. According to Article 51 of the Civil Code of Ukraine, legal regulatory instruments regulating the business activity of legal entities are applied to the entrepreneurial activity of natural entities, unless otherwise provided by law or does not follow from the essence of relations. The above is another argument in favour of the fact that individual entrepreneurs can be parties to a contract of rent (Pospolitak, 2010).

As a result of the research carried out by us, it was established that, in accordance with the current legislation and the absence of direct prohibitions, the parties (entities) of rental relations could be:

- natural entity (rent payer) - natural entity (rent recipient);

- natural entity (rent payer) - legal entity (rent recipient);

- legal entity (rent payer) - natural entity (rent recipient);

- legal entity (rent payer) - legal entity (rent recipient).

This position is based on the fact that Article 732 of the Civil Code of Ukraine does not specify which of the parties can be specific natural entities and legal entities under the contract of rent. This gives grounds for asserting that both the payer and the recipient may be legal and natural entities, as well as, as stated in the publication (Pospolitak, 2010), the state and the territorial communities. 
Taking into account the above, for the purposes of rent accounting, the entities of the rental relations will be participants in the management relations, which, in accordance with the current legislation, are obliged to keep accounting records and prepare financial statements. Accordingly, the rent payer will have additional income and expenses associated with the payment of rent, and the rent recipient will have income, which will be subject to tax discharge.

Within the generalization of individual publications devoted to the legal regulation of rental relations, it was also established that the list of objects that can form rent is limited, since from the standpoint of the classical economy as a source of rent factors of production are considered: classical (labour, land (natural wealth), capital; modern (labour, capital, land, entrepreneurial skills, ecology, information, science). Awareness of the complexity, multiple-level system, institutional foundations of development, and important role of rental relations in the modern market economy allows us to depart from the narrow natural-resource interpretation of rent (Hrazhevska, 2015).

Rent as a type of income affects directly the optimization of the use of economic resources by enterprises, is important in determining priorities and shaping development plans. Business, focusing on demand satisfaction, defines the prospects, priorities of individual activities in line with potential profits, the size of which largely depends on the existing process of rent identification. The properly constructed process of rent identification contains a number of economic levers of influence on production, through which cooperation between individual links and participants in the production and commercial process, as well as the promotion of technology improvement and resource efficiency, is provided.

Focusing on long-term and stable development is a priority task of optimizing rental relations. An effective rental mechanism creates a prospect of sustainable development for business through a fair distribution of the added value created, namely through an adequate rate of profit on the use of resources that remains by commodity producers. It also impedes the receipt of economic rent by certain categories of market participants, as it leads to lack of income of the required level by others and negatively affects their motivation for efficient management and rational use of resources. Another task of the rental mechanism is the prevention of rent-guided behaviour, when different groups of the market participants, competing for rent, resort to unproductive costs, which can lead to inefficiency of production in general.

Market participants and, consequently, entities of the process of rent identification, are not only direct participants of resource use, namely, owners of resources, entrepreneurs and enterprises of various forms of ownership, which use these resources, but also intermediary structures and infrastructure organizations, which include wholesalers and exporters of products, banks and stock exchanges and transport companies. Various government authorities are also parties to the process of rent identification, whose role consists in the institutional regulation of rental relations at all levels of the production and commercial process, where creation, distribution, assignment, and withdrawal of rent is made.

The process of rent identification occurs under the influence of a large number of endogenous and exogenous factors, which determine the behaviour of participants in rental relations, affect the process of creation and distribution of income from the use of resources. At that, exogenous factors such as the legislative and regulatory activity of the government have the decisive influence, as a result of which there is the market infrastructure that creates a system of accumulation and appropriation of rent, the allocation and withdrawal of surplus profits.

Alongside with that, an endogenous factor such as an improved accounting system that will perform the below-listed task will play a decisive role:

- formation and provision of complete, timely, and reliable information on rental income for the effective management of the entity's business and its rental payments to the budgets of different levels;

- ensuring control over the use of rental resources (rent-forming factor), received rental income of a business entity;

- creation of sufficient information support for the analysis of rental income.

\section{Conclusions and perspectives of further research}

Transformation of the modern mechanism of fragmentary regulation of rental relations should occur systematically, with the obligatory improvement of methods of accounting for rental resources and development of a methodology for calculating rental income; system of taxation of extra profits taking into account specific sources and conditions for the formation of various types of rent; institutional regulation of forms of appropriation and withdrawal of rent by providing a clear specification of property rights; norm setting for production; appropriating, and withdrawal of various types of rent, limiting ineffective and stimulating their effective use in order to increase the competitiveness of the national economy and increase the well-being of the Ukrainian population.

The presented transformation can be realized under the conditions of accounting of results of rental relations. For this purpose, the legal and economic conditions for rent accounting were identified in the carried out research. 
In particular, it was established that the legal basis for an accounting of the results of rental relations is the identification of:

- entity, to which the object belongs (rent-forming factor (resource));

- entity, which uses the object (rent-forming factor (resource));

- mechanism of implementation of rental relations;

- undeniable grounds for calculating the rent-forming factor (resource) - the contract of rent or other legal instrument regulating the rental relations.

The economic preconditions necessary and sufficient for arrangement and keeping of rent accounting by the economic entity should include the establishment of:

- object - a rent-forming factor (resource), which is used (exploited) by the economic entity-rent payer;

- economic benefit from using (exploitation) of such object;

- economic advantage from using (exploitation) of such an object;

- income of the entity that uses (exploits) such an object that includes rent;

- rent estimation for determining rental income, the share of rent in income from a certain type of activity and further implementation of rent payment;
- documenting and accounting on the accounts of the rent accounting (rental income) and rent payment, followed by their reflection in the financial statements of the economic entity-rent payer.

Thus, at the economic entity's level, rent accounting is necessary for the effective management by the entity itself. Based on strategic goals, the owner or user of rental resources that receives a significant amount of rent from their particular type may decide to invest additional costs to improve these resources in order to increase the amount of the rent received or spend them for improving other types of resources that are worse by their properties and do not generate income from their use.

So, the introduction of such a category as rent into the accounting system should become one of the topical issues among the scientists-accountants who investigate rental relations in Ukraine.

Prospects for further researches are to improve the mechanism of rent relations on the basis of defined economic and legal preconditions for rent accounting; classification of types of rent, as well as existing proposals as to reflection of rent in the accounting system from the use of existing and innovative rent-forming factors in the economic activity, which will approach to the maximum implementation of the provisions of the concept of sustainable development.

\section{References:}

Anomalii v tsyvilnomu pravi Ukrainy : navch.-prakt. posibnyk (2007). [Anomalies in the civil law of Ukraine : practical study guide] EiC R. A. Maidanyk. K. : Justinian, 912 p.

Apanasiuk M. P. (2004). Dohovir renty: avtoref. dys. na zdobuttia nauk. stupenia kand. yuryd. nauk: spets. 12.00 .03 [Contract of rent : extended thesis abstract for Cand. Sc. (Jurisprudence): 12.00.03]. Kharkiv National University of Internal Affairs. Kharkiv, 15 p.

Bazylevych V.D. (2008). Makroekonomika [Macroeconomics: Textbook]. 4th Edition, Revised and Expanded. K.: Znannia, 743 p.

Baliuk V. M. Suttievi umovy dohovoru renty [Essential terms of the contract of rent] [Electronic resource] Available at: http://www.nbuv. gov.ua/portal/soc gum/znpkhnpu/Pravo/2008_10/Balyuk. pdf. - Title from the screen.

Bodnar O.V. (2017) Renta v systemi vartisnykh kontseptsii [Rent in the system of value concepts] Scientific Herald of Kherson State University. Series: Economics Sciences. Issue 23, p. 65-69.

Vehera S.H. (2011). Razvytye metodolohyy bukhhalterskoho ucheta zemly v kontekste sovremennoi teoryy renty [Development of the methodology of land accounting in the context of modern theory of rent] [monograph]. Novopolotsk: PSU, 464 p.

Hrazhevska A. (2015). Struktura ta kharakterni oznaky systemy suchasnykh rentnykh vidnosyn [Structure and characteristic features of the system of modern rental relations]. Bulletin of Taras Shevchenko National University of Kyiv. Economics. 11 (176), p. 13-16.

Hurovska T.V. (2011). Teoriia renty: istoriia ta suchasnist [Theory of rent: history and the present] Herald of Khmelnytskyi National University. Economic Sciences, Vol. 1, №6, p. 7-11.

Dvihun A.O. (2008). Rentna polityka ta yii rol u realizatsii finansovoi stratehii derzhavy [Rent policy and its role in the implementation of the financial strategy of the state] World of Finance. Issue 3, p. 73-77.

Economic Dictionary (1973). Edited by P.I. Bahrii, S.I. Dorohuntsov. Chief editorial board of the Ukrainian Soviet Encyclopaedia of the Academy of Sciences of the Soviet SSR. Kyiv, 622 p.

Economic Encyclopaedic Dictionary (2006). In 2 Vols. Vol. 2 / edited by S.V. Mochernyi. Lviv: Svit, 568 p.

Zhuk V.M. (2012). Bukhhalterskyi oblik: shliakhy vyrishennia problem praktyky i nauky [Accounting: ways to solve problems of practice and science] [monograph] K.: NSC "Institute of Agrarian Economics", 454 p.

Zamula I.V. (2010). Bukhhalterskyi oblik ekolohichnoi diialnosti u zabezpechenni stiikoho rozvytku ekonomiky [Accounting of ecological activity in ensuring sustainable development of the economy] [monograph]. Zhytomyr: ZhSTU, $440 \mathrm{p}$.

Zakharchuk O.A. (2011). Rentnyi kharakter platezhiv za resursy [The rent character of payments for resources]. Ekonomika ta Derzhava, №3, p. 89-91. 
Zdan (Melnyk) S.I. (2011). Problemy vidobrazhennia rentnoho dokhodu promyslovykh pidpryiemstv v bukhhalterskomu obliku [Problems of reflection of rent income of industrial enterprises in accounting]. International collection of scientific works. Issue 1(19), p. 178-183.

Zeldner A.H. (2003). Hosudarstvo i ekonomyka: Faktory rosta: monohrafyia [State and economy: growth factors: monograph] RAS, Institute of Economics. M.: Nauka, 214 p.

Convention between the Government of Ukraine and the Government of the Italian Republic on Avoidance of Double Taxation of Income and Capital and Prevention of Tax Evasion (Art. 18) Kyiv, 26 February 1997 [Electronic resource]. Available at: www.zakon.rada.gov.ua

Convention between the Government of Ukraine and the Government of the Republic of India on Avoidance of Double Taxation and Prevention of Tax Evasion with Respect to Taxes on Income and Capital (Art. 19) Kyiv, 7 April 1999 [Electronic resource]. Available at: www.zakon.rada.gov.ua

Convention between the Government of Ukraine and the Government of the Federal Republic of Brazil on Avoidance of Double Taxation and the Prevention of Tax Evasion with Respect to Income Taxes (Art. 18) Kyiv, 16 January 2002 [Electronic resource]. Available at: www.zakon.rada.gov.ua

Kudriashova R.P. (2003). Renta v sovremennoi ekonomyke Rossyy: teoryia i praktyka: monohrafyia [Rent in the modern Russian economy: theory and practice: monograph] Samara State Economic Academy - Samara: Publishing of Samara State Economic Academy, 149 p.

Kuzyk B.N. (2004). Russia - 2050: Innovative Breakthrough Strategy. Economics, 632 p.

Lukinov I.I. (1964). Tsenoobrazovanye y rentabelnost proyzvodstva selskokhoziaistvennykh produktov [Pricing and profitability of agricultural production] M.: Kolos, 423 p.

Meshcherov V.A. (2006). Sovremennye rentnye otnoshenyia: teoryia, metodolohyia i praktyka khoziaistvovanyia [Modern rental relations: theory, methodology, and practice of management] Economic Sciences, $312 \mathrm{p}$.

Moshenets O.V. (2009). Evoliutsiia rentnykh vidnosyn: vid klasychnoi shkoly do teorii suspilnoho vyboru [Evolution of rental relations: from classical school to the theory of social choice]. Agrosvit, №7, April, p. 41-44.

Osadcha T.S. (2016). Metodolohiia bukhhalterskoho obliku ta analizu renty: monohrafiia [Accounting methodology and analysis of rent: monograph]. Zhytomyr: PE "Ruta", 292 p.

Ostapchuk T.P. (2012). Zemelna renta v systemi bukhhalterskoho obliku [Land rent in the accounting system] Herald of Donetsk National University of Economics and Trade named after Mykhailo Tugan-Baranovsky. № 3 (55), p. 376-382.

Pankov D.A. (2009). Metodolohichni problemy obliku zemli i zemelnoi renty renty [Methodological issues of land registration and land rent] Problems of the theory and methodology of accounting, control, and analysis. International collection of scientific works. Series: Accounting, control, and analysis. Issue 3 (15). Zhytomyr: ZhSTU, p. 36-43.

Paskhaver B.I. (1972). Rentni problemy v SRSR [Rent problems in the USSR] K.: Naukova Dumka, 191 p.

Pospolitak V.V. Khanyk-Pospolitak R.Yu. (2010). Aktualni pytannia dohovoru renty [Topical issues of the rental agreement] Scientific Papers. Volume 103. Legal Sciences, p. 85-90.

Sagaidak A.E. (1992). Ekonomycheskyi mekhanyzm realyzatsyy zemelnoi sobstvennosty v uslovyiakh rynka: avtoreferat dys. na soyskanye uch. step. d.e.n. [The economic mechanism for the realization of land property under market conditions: extended thesis abstract for Dr. Sc. (Economics)] M., 36 p.

Sukhanov E. A. (2005). Civil law: in 4 Vols. 3rd Edition, Revised and Expanded. M.: Wolters Kluwer, Vol. 3: Law of obligations, $800 \mathrm{p}$.

Zaichuk O.V., Kopylenko O.L., Onishchenko N.M. [at al.] (2009). Modern Legal Encyclopaedia. Legislation Institute of the Verkhovna Rada of Ukraine. K.: Yurinkom Inter, 384 p.

Agreement between Ukraine and the Republic of Tajikistan on Avoidance of Double Taxation and Prevention of Evasion of Taxes on Income and Capital (Art. 18) Yalta, 7 September 2002 [Electronic resource]. Available at: www.zakon.rada.gov.ua

Shyshka R.B. (2006). Civil law of Ukraine: a series of lectures: in 6 Vols. Kharkiv : Espada,- Vol. 5. Book 2. Contractual law : P. 1. General terms and agreements for property transfer, p. 281-307.

Bilousov Yu.V., Lozinska S.V., Rusu S.D. (2005). Civil law of Ukraine: study guide. K.: Pretsedent, 448 p.

Kharytonov Ye.O., Kalitenko O.M. (2004). Civil Code of Ukraine: Commentary. Odesa: Yurydychna Literatura, 1110 p.

Shpychak O.M. (2000). Prices, costs, profits of agricultural production and infrastructure of food markets of Ukraine. K.: IAE AASU, 585 p. 